\title{
The Role of 'Belladonna 200' in the Prevention of Japanese Encephalitis (JE) Virus Infection
}

\author{
Bhaswati Bandyopadhyay et al.* \\ School of Tropical Medicine, Kolkata \\ India
}

\section{Introduction}

With the advent of modified improved JE vaccines, JE preventive program is now going on in full swing throughout the globe, particularly in South-East Asian countries where the disease is highly prevalent. However, recent unswerving studies indicated that we should not satisfy ourselves with the belief that we could be able to stop the spread of this dreaded disease in near future. This is because as much as forty per cent infected children was found vaccinated questioning the efficacy of the vaccines itself, which are currently in use and frequent failures to access the deep rural areas, and in the vast forest areas by the dedicated trained vaccination team due to uninterrupted seasonal and other natural catastrophes which becomes a major setback in the program. Thus although almost all developing countries in the endemic zones have accepted the control program by vaccination, but the outcome of such an elaborate and difficult protocol appears gloomy. It is true that a speculative encouraging approach may not be practically feasible in a wide scale vaccination program considering the unreachable vast tropical rural areas and taming a gigantic inadequately educated population from aversion in participation in such a vaccination program.

There are also failures of vaccination of the JE reservoirs too. Thus it becomes a worthless approach when we try to vaccinate a pig population due to their extremely rapid growing population in a herd. Controlling the vectors is also an uphill task which appears totally frustrating due to difficult natural scenario of the vector breeding areas in the endemic zones.

All these aspects straightforwardly indicate that we should search all other possibilities in controlling this problematic disease taking a toll of young lives and creating a sizable disabled population in the society. In such an attempt we find some evidences that a homeopathic medicine "Belladonna" is used by some homeopathic practitioners in individuals to protect them from JE. Thus this paper contains details of our study to find out if there is any real protective role of this medicine in JE. This experiment was done in two different models - JE pock formation on chick chorioallantoic membrane (CAM) and JE infection of suckling mice by intracerebral route where mother of the litter was treated with

\footnotetext{
* Satadal Das ${ }^{2}$, Milan Sengupta ${ }^{1}$, Chandan Saha ${ }^{1}$, Chinta Raveendar2, Rathin Chakravarty ${ }^{2}$, Chaturbhuja Nayak ${ }^{2}$ Anil Khurana ${ }^{2}$ and Krishnangshu Ray ${ }^{1}$

${ }^{1}$ School of Tropical Medicine, Kolkata, India

${ }^{2} \mathrm{CCRH}$, Department of AYUSH, Government of India, New Delhi, India
} 
the medicine. This chapter contains details of these studies where we could find a bright outlook of such a preventive measure. This chapter also contains details of the procedures regarding studies of JE virus on CAM which is not available in details elsewhere in any published text books or journals, as this was standardized by us, and similarly although JE virus infection in suckling mice is well known but formulating a protocol of the study on prevention by treating mothers is a new approach. Thus these methodology details will be helpful for those who are working in this field or are going to learn more regarding these aspects in future.

\section{Materials and methods}

\subsection{Place of study}

This chapter is based on the study conducted at the Virology unit, Department of Microbiology, School of Tropical Medicine, Kolkata.

\subsection{Mice animal model}

The most common choice of host for isolating arboviruses is still the suckling mice. In this experiment, Swiss albino mice, Webster strain were used after obtaining permission from the Ethical Committee of the Institute. The animals were maintained in the mice colony of School of Tropical Medicine, Kolkata.

\subsection{The JE virus}

In this experiment the virulent Nakayama strain (Source human, year 1935, location Japan, GenBank accession no. EF571853, Genotype III) was used.

\subsection{The medicine}

Belladonna is a well known medicine used by homeopathic practitioners in symptoms of encephalitis. Thus Raue described as early as 1885 that Belladonna is indicated in diseases of nerve and brain characterized by the violent headache, drowsiness and delirium; dilated pupils; double sight (Raue 1885, reprinted 1975). There are different Belladonna preparations available in the market but in this study we used aqueous preparation of Belladonna 200 which was procured commercially. The medicine was prepared according to standard procedures advocated by Homeopathic pharmacopoeia of India (Ministry of Health, Government of India, 1971,1:1,7-16,72). Initially we started experiment with Belladonna 6 and although average survival time of the suckling mice of treated mothers after inoculation of the virus was increased from $36 \mathrm{~h}$ in controls to $50 \mathrm{~h}$, but all the mice died (unpublished data). Later we found that C. V. Boenninghausen, a veterinary doctor as well as a renowned homeopathic practitioner described in 1843 that Belladonna 200 is the ideal medicine in experiments with mice. Thus we used Belladonna 200 in all successive lots in this experiment.

\subsection{Egg inoculations (Bandyopadhyay et al, 2010)}

For preventive studies one dose $(50 \mu \mathrm{l})$ of the aqueous dilution of the selected medicine was inoculated in the chorioallantoic membrane followed by the administration of $50 \mu \mathrm{L}$ of the 
JE viral suspension, 5-10 minutes later. The chorioallantoic membrane consists of an outer layer of stratified epithelium which constitutes the respiratory surface of the egg and an inner layer of endoderm (the lining of the allantoic cavity).

Dermotropic viruses (poxviruses and some herpes viruses) and JE viruses grow on this membrane, and at low concentrations, they produce discrete foci of cell proliferation and necrosis (pocks). The membrane was therefore used to assay JE viruses in this study. Different viruses cause pocks of different color and morphology, and this is also of diagnostic value for distinguishing between different viruses. One day old fertile hen's (White leghorn) eggs were obtained from State Poultry Farm of Govt. of West Bengal, Tollygunge, Kolkata. They were collected from healthy flocks which were maintained on a well balanced and antibiotic free diet. The eggs were incubated at $370 \mathrm{C}$ within a special egg incubator with $65 \%$ humidity. Eggs were turned mechanically twice a day. After 5-6 days of incubation, egg checking was done and the fertile eggs were selected by candling and the sterile eggs along with the eggs with dead embryos were rejected.

On the $12^{\text {th }}$ day eggs were then candled with the help of an illuminator in a dark room to check viability, movements of embryos and define the area of blood vessels. The air space was marked on the egg shell with a pencil and a point was selected on CAM avoiding injury of large blood vessels. The air space was punctured with a pointed end of hand punch. The shell was also punctured after clearing with a sterile cotton swab on the marked spot over the CAM, using the hand punch with slight rotatory motion, avoiding injury to the shell membrane. The shell dust was blown away with capillary pipette. A drop of sterile normal saline was placed inside over the inoculation site. The tip of the blunt instrument was inserted through the drop of saline. Slight suction with a rubber teat over the hole at the blunt end of the egg was done to have a complete dropping of the membrane confirmed by candling.

The inoculum was deposited on the CAM with the help of tuberculin syringe, and the inoculated egg was rotated to facilitate the dispersion of the inoculum. The hole in the air sac was sealed and the inoculated eggs were incubated at $37^{\circ} \mathrm{C}$ for $48 \mathrm{hrs}$ in a horizontal position. After 48 hours the CAM was harvested aseptically after the shell membrane was broken with a blunt forceps for maximum exposure of the CAM. The membrane was cut out with a sterile pair of scissors and placed in a Petri dish for further examination.

\subsection{Control study}

Japanese encephalitis virus $(50 \mu \mathrm{l})$ in the same concentration $\left(10^{-3}\right)$ in bovine albumin phosphate saline (BAPS), pH 7.20 mixed with equal volume $(50 \mu \mathrm{l})$ of sterile pyrogen free water was also inoculated on CAM. The pock count of this control virus study was considered as baseline data and any deviation from this baseline was noted after application of different medicines in the test series/group. An initial experiment was also done with different concentrations of viruses to find out the dilution which gave the maximum number of pocks on CAM (optimum dilution). If during the study, there was death of the inoculated eggs or membranes were not formed properly the data of that lot were excluded.

Apart from this virus control experiment, similar control studies were also done with the medicine without the virus in equal dilutions with sterile water. Bovine albumin in phosphate saline $\mathrm{pH} 7.2$ was also studied similarly as viral dilutions were done with this buffer. 


\subsection{Observation of growths on CAM}

Inoculated CAMs were observed after 48 hours of inoculation particularly to see the formation of pocks and other associated changes on CAM.

\subsection{Standardization of the viral inoculums in suckling mice}

The virulent Nakayama strain virus was consecutively passed three times in mice, and the virus suspension was prepared from the third stage which was designated as the $10^{-1}$ stock suspension. For determination of a $50 \%$ lethal dose $\left(\mathrm{LD}_{50}\right)$, several lots of suckling mice were injected intracerebrally (i.c.) with dilutions of the stock suspension from $10^{-1}$ to $10^{-9}$. All the inoculated suckling mice were observed daily to note their survival and following this $\mathrm{LD}_{50}$ value was calculated by a standard method ( Reed and Muench, 1938).

\subsection{Methods of inoculation of suckling mice (Bandyopadhyay et al 2011)}

This was done following the method described by Gould and Clegg (1985). One paper towel was placed on a cork board inside the safety cabinet. One sterile disposable syringe $(1 \mathrm{~mL})$ with 26-gauge sterile disposable needle was loaded with appropriate inoculums after wearing disposable gloves and with hands well inside the safety cabinet. The suckling mouse was then placed on the paper towel. It was gripped firmly and $0.02 \mathrm{~mL}$ of the sample was inoculated into one of the cerebral hemisphere penetrating no more than $1.5 \mathrm{~mm}$. The needle is kept in position for 2 seconds then removed slowly. The procedure was repeated until the complete litter had been inoculated. For determination of $\mathrm{LD}_{50}$ dose, inoculations were commenced with the highest dilution, so that the same needle and syringe could be used with each viral dilution. After completing inoculations each litter was returned to its mother, the cage was properly labeled and kept in the rack. Mice showing severe disease signs or those that died within $2 \mathrm{~h}$ of observation were immersed in a closed vessel containing chloroform and later discarded according to statutory guidelines for Biomedical Waste management.

\subsection{Method of inspection and virus collection}

During inspection the condition of each mouse was recorded as D (dead), S (sick), N (normal), or M (Missing). However, in this experiment there was no $\mathrm{M}$ category. When the infected brain was collected for preparation of the inoculums, the dead mouse was pinned on to the cork board placed over two paper towels, one pin was placed through the nose and the other through the base of the tail. The mouse was then soaked with sufficient amount of rectified spirit and the scalp was removed using one pair of sterile scissors and forceps. This was done by cutting across the back of the scalp using scissors that have a pointed and a blunt blade. The pointed blade of the scissors was inserted into the soft rear centre point of the skull and the outside was cut down towards the nose. The skull cap was then lifted up and the brain was removed by the closed ends of the scissors.

\subsection{Disposal procedure}

All mice, paper towels, gloves and disposable instruments were disposed according to standard guidelines for Biomedical Waste management. 
The cages and the instruments were sterilized and the safety cabinet was thoroughly cleaned with disinfectants.

\subsection{Experimental design}

Suckling mice (2-3 days old) were taken from litters in which mothers were orally fed with $0.06 \mathrm{~mL}$ of Belladonna 200 for $7 / 14$ days. In control experiment, suckling mice were similarly taken in which mothers were not orally fed with the medicine. After this, suckling mice of both the groups were challenged with $0.02 \mathrm{~mL}$ of the supernatant of clarified JEV infected mice brain emulsion $(10 \%)$ diluted to a $\mathrm{LD}_{50}$ dose intracerebrally and observed for 30 days post inoculation period. All the mice were observed daily after inoculation and every four hours after the onset of clinical signs. Clinical signs of the disease in mice particularly in last 24 hours were refusal to feeds, became disarranged in the nest, tremors and muscular spasms, ataxia, and hind-limb paralysis followed by death within a few hours. Those suckling mice that died within the first 24 hours was considered as non-specific deaths.

For preparation of infected brain emulsion required for $\mathrm{LD}_{50}$ determination and standardization of the inoculums, brains were collected close to the time of death. When the animal showed acute signs of uniform sickness (usually on third post inoculation day), their brains were harvested aseptically. The brains after weighing, were ground in a homogenizer (Lourde's homogenizer) placed in ice bath to give a $10 \% \mathrm{w} / \mathrm{v}$ suspension in BAPS with antibiotics. The suspension was initially centrifuged at $2000 \mathrm{rpm}$ at 4 degree $C$ for 15 minutes, following which the supernatant was recentrifuged at 10,000 rpm at 4 degree $C$ for one hour (in a refrigerated centrifuge). The supernatant was carefully collected and was kept in small aliquots of $0.5 \mathrm{ml}$ screw capped vials, labeled and sealed and stored at -70 degree $C$ deep freezer after shell freezing. Throughout the entire study, the passage level of the stock mice was maintained constant. For this purpose, stock of the virus, one or two passages prior to the working stock was stored at -70 degree $C$. Whenever the working stock got exhausted or the titer of the stock fell short by one log due to prolonged storage suckling mice were inoculated with the back passage material and fresh working stock of the same passage level was prepared.

\subsection{Histological studies}

Macroscopically presence of congestion, swelling, petechial haemorrhages and microscopically evidences of neuronophagia, microglial nodules, intranuclear/intracytoplasmic inclusion bodies, inflammatory cell cuffing in the Virchow-Robin spaces, reactive features of astrocytosis, diffuse microglial activation were studied with the brain specimens taken out from the suckling mice in different experimental groups including the control group.

\section{Results}

\subsection{CAM experiment}

Optimum dilution of the viruses was studied with different concentrations of the viruses Neat $(10 \%), 10^{-1}, 10^{-2}, 10^{-3}, 10^{-4}, 10^{-5}$, control (buffer solution without viruses). The results showed that $10^{-3}$ dilution showed maximum pock count and thus this optimum concentration was used throughout the experiment. Results of different experiments with 
Belladonna 200 are given in Table 1. Control studies with different medicines and bovine albumin phosphate saline showed normal findings.

\begin{tabular}{|l|l|l|}
\hline Experiment & $\begin{array}{l}\text { Pock count on CAM in } \\
\text { number (Average } \pm S D \pm S E M)\end{array}$ & $\begin{array}{l}\text { t-value of the difference and } \\
\text { its significance }\end{array}$ \\
\hline Belladonna 200 (N-300) & $\begin{array}{l}53.97 \pm 28.21 \pm 4.70 \\
\text { Virus control }\end{array}$ & $\begin{array}{l}\text { 6.95, P value highly } \\
\text { significant at } 0.01 \text { level }\end{array}$ \\
Virus + Medicine
\end{tabular}

$\mathrm{CAM}=$ Chorioallantoic membrane, $\mathrm{SD}=$ Standard deviation, $\mathrm{SEM}=$ Standard error of mean. $\mathrm{N}=$ Number of inoculated eggs. Eggs that were dead or yielded deformed or absent CAM, were not considered for calculation of the results.

Table 1. Changes in pock count on CAM with "Belladonna 200".

\subsection{Suckling mice experiment}

$\mathrm{LD}_{50}$ of the virulent Nakayama strain JE virus was $7.0 \log _{10} / 0.02 \mathrm{~mL}$. The average survival rate of the control group $(n=96)$ where mothers were not treated with the medicine was $47.92 \%$ (Fig.1), similar rate in the experimental group $(n=67)$ of suckling mice where mothers were treated with Belladonna 200 for $7 \mathrm{~d}$ was $80.60 \%$ (Fig.2), and the rate in the last experimental group $(n=53)$ of suckling mice where mothers were treated with the medicine for 14 days was $79.24 \%$. Details of the outcome of this study and statistical analysis $\left(\chi^{2}\right.$ test) are given in Table 2 . The statistical analysis ( $\chi^{2}$ test) indicated a highly significant difference with $\mathrm{p}$ value significant at 0.01 levels. Histological studies showed variable changes in the virus inoculated control group while in the test group there was no change in any of the survived mice after the challenge.

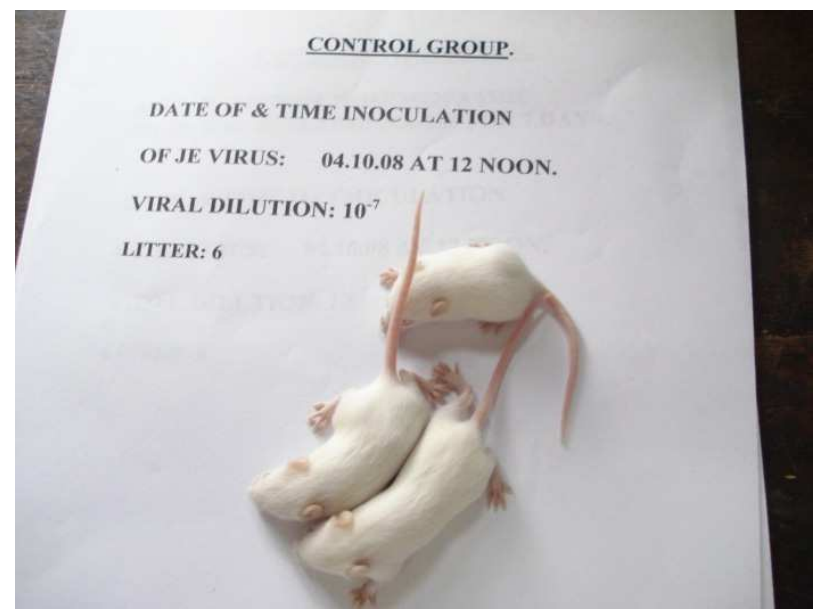

Fig. 1. Three alive mice in control group ( 3 survived out of 6 inoculated suckling mice, lot 1 ): 30 days observation 


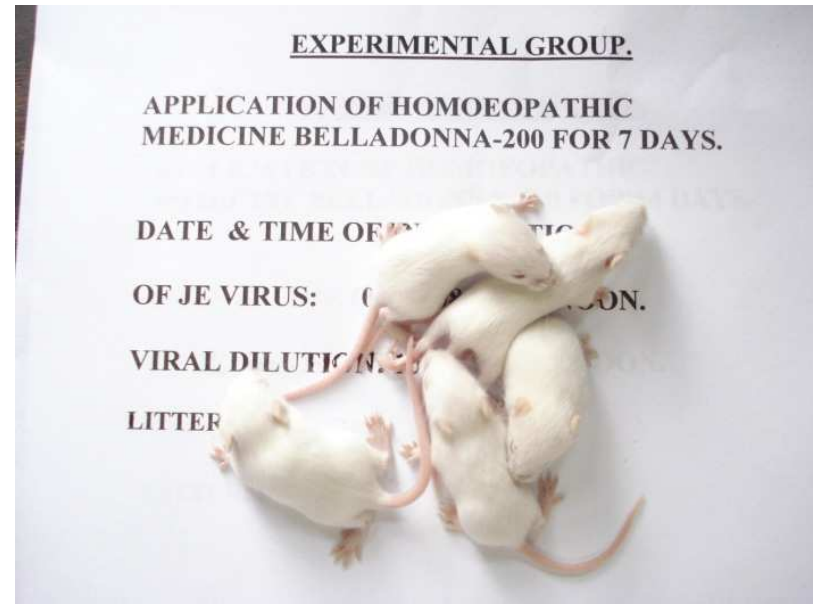

Fig. 2. Five alive mice in Experimental group1 (5 survived out of 6 inoculated suckling mice, lot 1): 30 days observation

\begin{tabular}{|l|l|l|l|l|}
\hline Parameters & $\begin{array}{l}\text { Control } \\
\text { group: } \\
\text { (Sucklings of } \\
\text { untreated } \\
\text { mother mice) }\end{array}$ & $\begin{array}{l}\text { Experimental } \\
\text { group 1: } \\
\text { (Sucklings of } \\
\text { Mother mice } \\
\text { treated with } \\
\text { Belladonna 200 } \\
\text { for 7 days) }\end{array}$ & $\begin{array}{l}\text { Experimental } \\
\text { group 2: } \\
\text { (Sucklings of } \\
\text { Mother mice } \\
\text { treated with } \\
\text { Belladonna 200 } \\
\text { for 14 days) }\end{array}$ & Total \\
\hline Attacked with JE & 50 & 13 & 11 & 74 \\
\hline Not attacked with JE & 46 & 54 & 42 & 142 \\
\hline Total & 96 & 67 & 53 & 216 \\
\hline Expected attacks $(50 \%)$ & 48 & 33.5 & 26.5 & \\
\hline $\begin{array}{l}\text { (Observed-Expected) })^{2} \\
\text { (Observed-Expected })^{2}\end{array}$ & 0.08 & 420.25 & 240.25 & \\
\hline $\begin{array}{l}\text { (Expected) } \\
\left(\chi^{2} \text { test) }\right.\end{array}$ & 12.54 & 9.07 & $\begin{array}{l}21.69(\mathrm{p} \\
\text { value } \\
\text { significant } \\
\text { at 0.01 level) }\end{array}$ \\
\hline
\end{tabular}

Table 2. Statistical analysis ( $\chi^{2}$ test) showing significant protective action of Belladonna 200 in suckling mice challenged with $\mathrm{LD}_{50}$ dose of virulent Nakayama strain of JE virus when mothers were fed with the medicine.

\section{Discussion}

Japanese encephalitis(JE) is basically a zoonotic disease where ardeoid water birds mainly herons and egrets are the reservoirs with frequent spread out even in epidemics to pigs, members of the family of equidae mainly horses and donkeys as well as in humans. The central vector of the disease is zoophilic Culex tritaeniorhynchus related to the $C x$. gelidus complex. It principally affects central nervous system and can produce severe neurological complications and even death (Okuno, 1978). 
This disease is currently prevalent in south Asia, south east Asia, east Asia and in the Pacific with a 3 billion population at risk, an annual incidence of 30,000 to 50,000 cases, with 10,000 to 15,000 annual deaths (Solomon, 2006) and a global impact of about 7,00,000 disabilityadjusted life years (DALYs)(WHO,2008). Local incidence rates usually range from 1-10 cases per 100,000 populations but can reach more than 100 cases per 100,000 populations during outbreaks. Among countries particularly India, Nepal, Thailand, Malaysia, Myanmar, Japan, China, Indonesia, Bangladesh extending in a wide zone from Pakistan to Siberia and Japan where the disease is now prevalent, in seven countries JE virus infection is presently increasing with a significant percentage of total population living in rural JE-endemic area (Fig.3) and among these countries DALYs are the greatest in India (Fig.4).

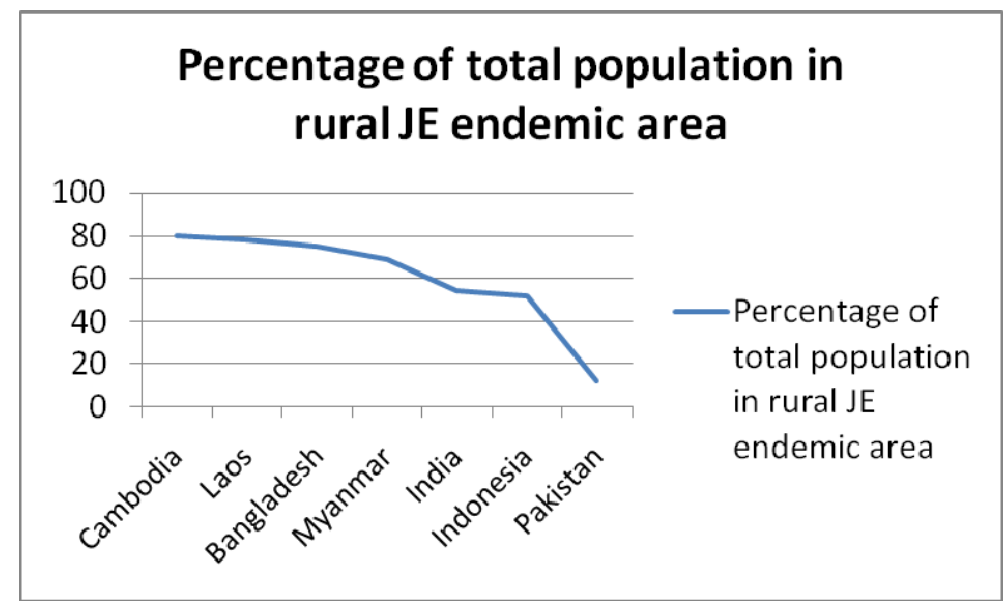

Fig. 3. Percentage of total population living in rural JE endemic area in countries where JE virus infection is increasing.

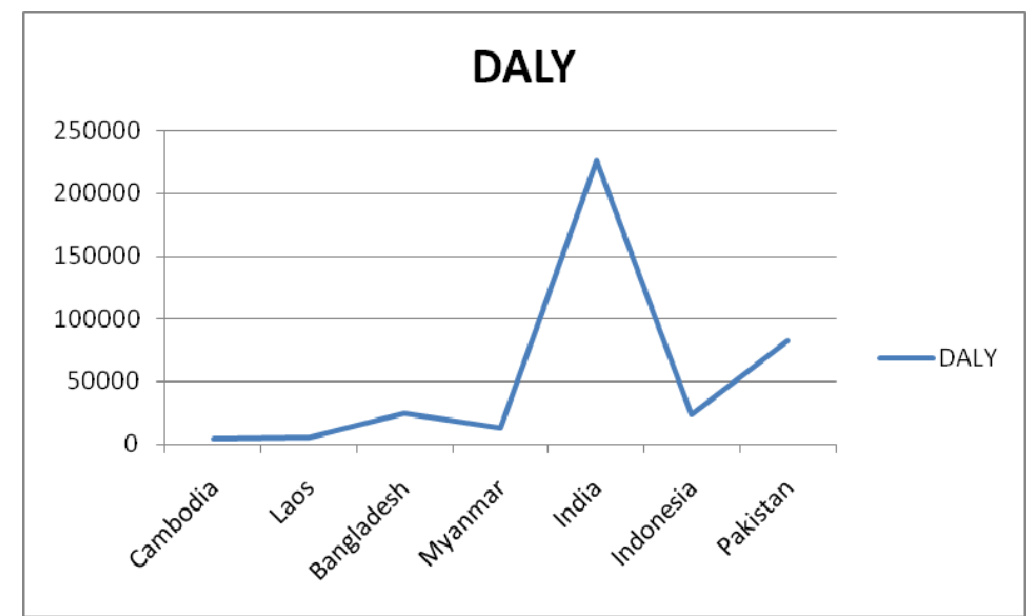

Fig. 4. Disability-adjusted life years (DALYs) in countries where JE virus infection is increasing (prepared with data obtained from various sources). 
Recently more than 1300 children died in outbreaks of JE in the north eastern state of Uttar Pradesh, although possibility of other enterovirus infection mixed with JE virus has not been ruled out.

Live attenuated vaccine against JE was developed about 40 years back (Igarashi,2002) and newly developed vaccines like live inactivated yellow fever virus - chimeric vaccine (Solomon, 2006) and adjuvanted SA 14-14-2 vaccine (E. Tauber and S. Dewasthaly, 2008) grown on Vero cell lines, are not only safe but also effective in single doses. However, two important obstacles for an effective vaccination program are there which are very difficult to solve: difficulties in delivering the vaccine in rural poor population and failures of vaccination in newborn pigs having maternal antibodies and with a high turnover rate of their population.

Experiments on intermittent irrigation (alternate wetting and drying) of paddy fields was found effective in vector control but its implementation is also very complicated because all paddy fields could not be covered simultaneously in such a program due to a vast area, sufficient water may not be available in rice-growing season and countrywide educational as well as supportive program may not be practicable (Rajendran et al, 1995). The transmission of JE virus is multi-factorial with at least five variables directly or indirectly influences the rate at which the virus is transmitted - the viral strain, vector, wild vertebrate hosts, humans, and environmental factors; thus incomplete targeting to one factor has got very little influence in this complex system of transmission.

Alterations in temperature and rainfall patterns induced by recent global climatic changes may lead to a significantly increased vector population in the endemic areas which will be very difficult to control.

Chemical control of the vectors with pyrethroids, organophosphates, carbamates etc. was also not found suitable due to their short term effects and rising levels of insecticide resistance. (S. H. Karunaratne and J. Hemingway, 2000).

The disease usually starts as a flu-like illness with fever, headache, nausea, vomiting, weakness. Altered mental status usually occurs from mild confusion to agitation to coma. Seizures develop in about $66 \%$ children, while headache and meningismus are commonly found in adults. There is no specific medicine to treat the patients suffering from JE. According to the World Health Organization the disease is fatal in up to 30 percent of cases, and there is a possibility that those who survive may be disabled for life.

The homeopathic medicine Belladonna 200 is prepared with the root, and the leaves of Atropa belladonna, which is also known as Deadly Nightshade, Dwale, Black Cherry, Strygium and Strychnon. In ancient times, the Venetians named this plant as Belladonna because at that time ladies used a distilled product of the plant as a cosmetic; hence the name "Bella-donna" or beautiful lady. One important indication of Belladonna is its use as a medicine in the treatment of patients with cerebral congestion as mentioned in homoeopathic pharmacopoeia. In a previous study we also observed preventive role of Belladonna in JE virus infected chick chorio allantoic membrane (Bandyopadhyay et al, 2010).

Mosquitoes in the genus Culex have a strong tendency to ornithophagy probably due to relatively inactive thrombocytes present in birds because anti-thrombin peptides are probably less in the saliva of these mosquitoes, only recently they are gradually adapted to 
mammals. It appears that recent changes due to global warming will accentuate their behavior in adaptation and a great havoc in human population may occur in near future by this virus unless we are prepared.

Medicinal properties of Belladonna are known from times immemorial. Many homeopathic practitioners used it in prevention of JE, although there is no experimental proof in favor of it. This experiment clearly indicated preventive role of this medicine against JE which is statistically highly significant.

Although such action of Belladonna is difficult to explain we here propose a hypothetic action pathway of this medicine in preventing JE virus infection.

If we look into the occurrence of calystegines and related compounds in A. belladonna and related plants then it is obvious that these are present in significantly higher amounts (Fig.5) in A. belladonna (Draeger et al, 1995).

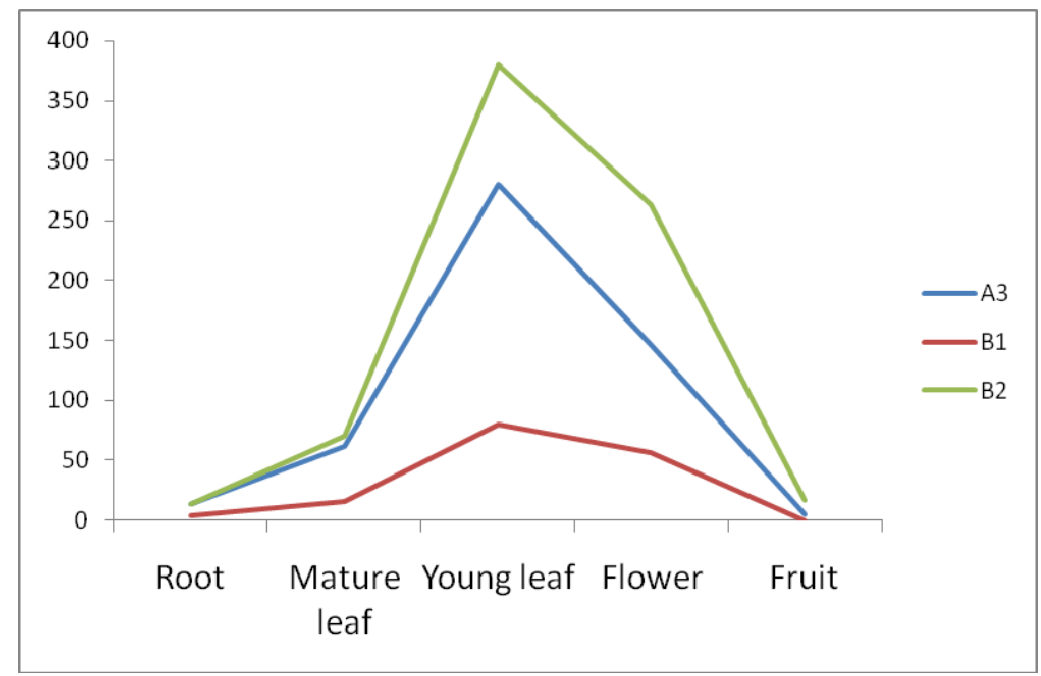

Fig. 5. High levels ( $\mu \mathrm{g} / \mathrm{g}$ fresh mass) of Calystegines (A3, B1, B2) in Atropa belladonna (based on the report by Draeger et al, 1995)

Calystegines are well known selective glycosidase inhibitors in comparison to common tropane alkaloids atropine and scopolamine of A. belladonna, which are parasympatholytic. Like most glycosidase inhibitors, calystegines compete with the substrate for binding to the active site as observed in kinetic interaction measurements. Most glycosidases perform enzymatic hydrolysis reaction with the aid of a glutamic acid residue in the active cleft and calystegines mimic the transition state of this reaction.

Most enveloped viruses like human immunodeficiency virus, hepatitis B virus etc. showed altered life cycle during invasion of cells in which glucosidase-mediated N-linked oligosaccharide trimming is inhibited and N-linked oligosaccharide processing events in the endoplasmic reticulum are important for the secretion of some enveloped viruses (Mehta et al, 1998) characterized by sequential trimming of the glucose residues on oligosaccharide precursor. 


\section{Belladonna200}

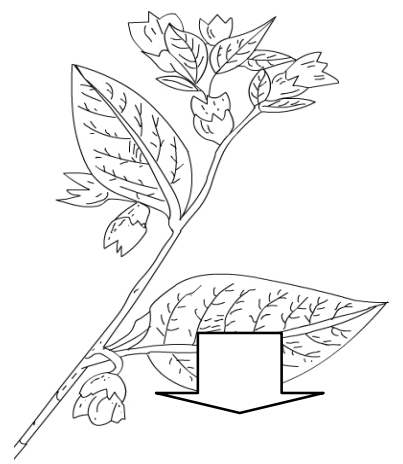

Calystegine A3 \& Calystegine B2

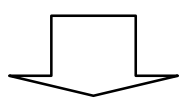

Competitive inhibition regarding glycosidase

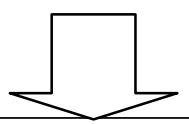

JEV entry in the cell is inhibited

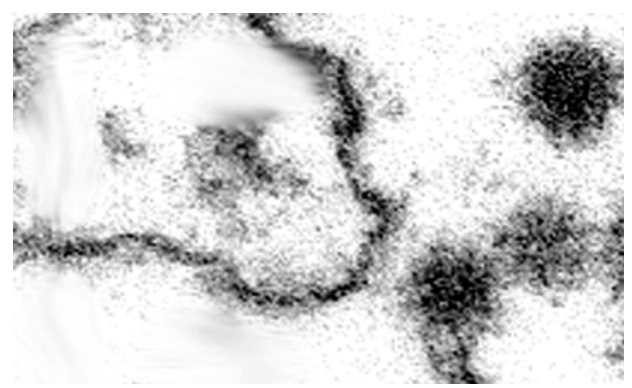

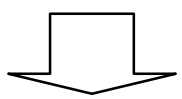

Decreased protein synthesis

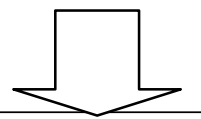

Jak-Stat signaling cascade target by JEV fails: Destruction of the virus by interferon

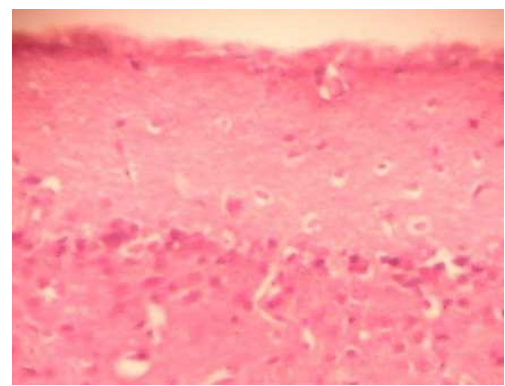

Fig. 6. The possible pathway of the action of Belladonna200 in prevention of JEV infection in mice. 
It has also been demonstrated that Dengue virus envelope glycoprotein processing in cells was strongly affected by this important mechanism (Courageot et al, 2000). Thus Belladonna may appear to act through this pathway in preventing JE virus infection in suckling mice (Fig.6). This also may lead to inhibition of the synthesis of key amino acid residues of the E protein of Nakayama strain JE virus(E107,Leu; E138,Glu; E176,Ile; E177,Thr; E264,Gln; E279,Lys; E315,Ile; E439,Lys) which are important for neurovirulence. It also blocks JE virus in evading action of interferon on them. Although interferon has been identified as the most promising antiviral agent against JE virus (Crance et al, 2003), but inside the body JE virus usually target the Jak-Stat ( Janus Kinasesignal transducer and activation of transcription) signaling cascade to evade the interferon response leading to failure of interferon treatment in JE infected children (Solomon et al, 2003). In this connection, it is important to note that cluster of genes encoding the interferon - induced 2'-5'-OAS ( 2',5'-Oligoadenylate synthetases) is present in chromosome 5 in mice- known also as Flv gene is responsible for susceptibility to JE virus infection in mice. ( Perelygin et al, 2002). It has been observed that some newly synthesized proteins are required to block Jak-Stat signaling by JE virus (Lin et al, 2004). Thus protein synthesis inhibitors may play a role in decreasing pathogenecity of JE virus where this medicine may play a role through the above mentioned pathways.

\section{Conclusion}

In a search to find out a newer method to prevent JE infection, we have studied "Belladonna 200" - a homeopathic medicine as a possible candidate which may fulfill our aim. Experiments utilizing two different models- CAM model and suckling mice model, both conclusively indicated that this medicine has got a definite role in preventing JE, the mechanism of which is still unknown. During the experiment we also standardized these two models which may help all future workers in this line.

\section{Acknowledgements}

This study was done as a part of the project study (No.17-88/20062007/CCRH/Tech/Coll/STM) financed by CCRH, AYUSH, Govt. of India. We thank Prof P.N.Gupta, Ex-Head of the Department of Microbiology, Medical College and Hospital, Kolkata for his valuable suggestions. We are thankful to the Institutional authorities and all the faculties of the Microbiology Department of School of Tropical Medicine, Kolkata, for their continued support and inspiration. We are also thankful to our technical personnel Surja Kumar Halder, Suniti Bikash Ghosh, Astom Chandra Adak, Pradip Ray, Kajori Mukherjee and Kartick Chandra Roy, for their dedicated participation in the project.

\section{References}

Bandyopadhyay B, Das S, Sengupta M, Saha C, Das K C, Sarkar D, Nayak C. 2010, Decreased intensity of Japanese encephalitis virus infection in chick chorioallantoic 
membrane under influence of ultradiluted belladonna extract. American J. Infectious Diseases, 6(2):24-28.

http://www.scipub.org/scipub/patch.php_

Bandyopadhyay B, Das S, Sengupta M, Saha C, Bhattacharya N, Raveendar C, Chakravarthy R, Ray K, Nayak C. 2011, Suckling Mice of "Belladonna 200" Fed Mothers Evade Virulent Nakayama Strain Japanese Encephalitis Virus Infection. International Journal of Microbiological Research, 2 (3): 252-257.

Courageot M, Frenkiel M, Santos C D D, Deubel V, Despres P. 2000, a-Glucosidase inhibitors reduce Dengue virus production by affecting the initial steps of virion morphogenesis in the endoplasmic reticulum, Journal of Virology, 74:1, 564-572. DOI:10.1128/JVI.79.14.8698-8706.2005

Crance JM, Scaramozzlno N, Jouan A, Garin D. 2003,Interferon, ribavirin, 6-azauridine and glycyrrhizin: antiviral compounds active against pathogenic flaviviruses. Antivir. Res. 58:73-79. DOI:10.1016/S0166-3542(02)00185-7

Draeger B, Van-Almssick A, Mrachatz G. 1995, Distribution of calystegines in several Solanaceae. Planta Medica, 61, 577-579. DOI:10.1093/jac/dkm 503

Igarashi A. 2002, Control of Japanese encephalitis in Japan: immunization of humans and animals, and vector control. Curr Top Microbiol Immunol, 267:139-52. DOI:10.3201/eid1411.071368

Karunaratne S H, Hemingway J. 2000, Insecticide resistance spectra and resistance mechanisms in mosquitoes, Culex tritaeniorrhynchus and Cx. gelidus, in Sri Lanka. Med Vet Entomol, 14:430-6. www. the free library.com.

Lin R-J, Liao C-L, Lin E, Lin Y-L. 2004, Blocking of the alpha interferon -induced Jak-Stat signaling pathway by Japanese encephalitis virus infection, Journal of Virology, 78:17, 9285-9294. DOI:10.1128/JVI..78.17.9285-9294.2004

Gould E A, Clegg J C S. 1985, Growth, titration and purification of Togaviruses, Mahy B W J(Ed) In Virology - a practical approach, IRL Press, Oxford, pp 43-74.

Mehta A, Zitzmann N, Rudd P M, Block T M, Dwek R A. 1998, a-Glucosidase inhibitors as potential broad based anti-viral agents, FEBS Lett. 430: 17-22.

Okuno T. 2006, An epidemiological review of Japanese encephalitis. World Health Stat Q. 1978, 31:120-33. Indian J Med Res 124, pp 211-212.

Perelygin AA, Scherbik SV, Zhulin IB, Stockman BM, Li Y, Brinton MA. 2002, Positional cloning of the murine flavivirus resistance gene. , Proc. Natl. Acad. Sci. USA, 99:9322-9327. DOI:10.1073/pnas.142287799.

Rajendran R, Reuben R, Purushothaman S, Veerapatran R. 1995, Prospects and problems of intermittent irrigation for control of vector breeding in rice fields in southern India. Ann Trop Med Parasitol, 89:541-9. PMID: 7495368

Raue C G. 1885, Special pathology and diagnostics with therapeutic hints, $4^{\text {th }}$ Ed, reprint 1975, Sett Dey \& Co, Calcutta, pp 915.

Reed L J, Muench H. 1938, A simple method of estimating fifty percent endpoints. Am J Hyg, 27:493-7.

Solomon T, Dung NM, Wills B, Kneen R, Gainsborough M, Diet TV, Thuy TT, Loan HT, Khanh VC, Vaughn DW, White NJ, Farrar JJ. 2003, Interferon alfa-2a in Japanese 
encephalitis: a randomized double-blind placebo-controlled trial. Lancet, 361: 821826. DOI: 10.1016/S0140-6736(03)12709-2. 38.

Solomon T. 2006, Control of Japanese encephalitis - within our Grasp? N Engl J Med, 355:869-71. DOI:10.1056/NEJMp058263 PMID:16943399.

Tauber E, Dewasthaly S. 2008, Japanese encephalitis vaccine - needs, flaws and achievements, Biol Chem, 389:547-50.

www.who.int/vaccine_research/diseases/vector/en/index5.html

World Health Organization. World Health Report (for years 2000-2004) 2008, available from http://www.who.int/whr/en. 


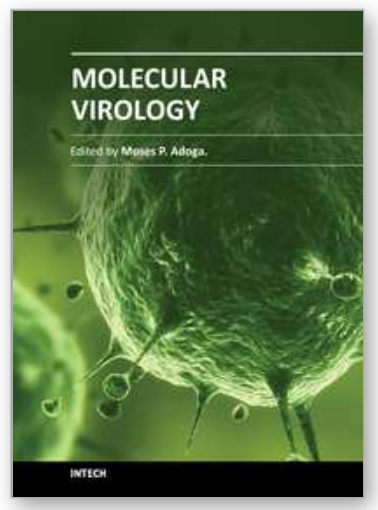

\author{
Molecular Virology \\ Edited by Mr. Moses Adoga
}

ISBN 978-953-51-0369-1

Hard cover, 168 pages

Publisher InTech

Published online 21, March, 2012

Published in print edition March, 2012

This book covers various aspects of Molecular Virology. The first chapter discusses HIV-1 reservoirs and latency and how these twin phenomena have remained a challenge to eradication. Aspects regarding the molecular evolution of hepatitis viruses including their genetic diversities with implications for vaccine development are treated in the second chapter. Metabolic disorders that are a consequence of hepatitis $\mathrm{C}$ virus infection are discussed in the succeeding chapter. The following two chapters discuss influenza $\mathrm{C}$ virus and the applications of viral vectors in therapeutic research. Avian influenza is handled in the sixth chapter and the therapeutic potential of belladonna-200 against japanese encephalitis virus infection is discussed in the succeeding chapter. The last two chapters discuss baculoviruses and their interaction with polydnaviruses. Researchers, lecturers and students will find this book an indispensable companion.

\title{
How to reference
}

In order to correctly reference this scholarly work, feel free to copy and paste the following:

Bhaswati Bandyopadhyay,Satadal Das, Milan Sengupta, Chandan Saha, Chinta Raveendar, Rathin Chakravarty, Chaturbhuja Nayak Anil Khurana and Krishnangshu Ray (2012). The Role of 'Belladonna 200' in the Prevention of Japanese Encephalitis (JE) Virus Infection, Molecular Virology, Mr. Moses Adoga (Ed.), ISBN: 978-953-51-0369-1, InTech, Available from: http://www.intechopen.com/books/molecular-virology/therole-of-belladonna-200-in-the-prevention-of-japanese

\section{INTECH}

open science | open minds

\section{InTech Europe}

University Campus STeP Ri

Slavka Krautzeka 83/A

51000 Rijeka, Croatia

Phone: +385 (51) 770447

Fax: +385 (51) 686166

www.intechopen.com

\section{InTech China}

Unit 405, Office Block, Hotel Equatorial Shanghai

No.65, Yan An Road (West), Shanghai, 200040, China 中国上海市延安西路65号上海国际贵都大饭店办公楼405单元

Phone: +86-21-62489820

Fax: $+86-21-62489821$ 
(C) 2012 The Author(s). Licensee IntechOpen. This is an open access article distributed under the terms of the Creative Commons Attribution 3.0 License, which permits unrestricted use, distribution, and reproduction in any medium, provided the original work is properly cited. 